\title{
Actinomyces massiliensis sp. nov., isolated from a patient blood culture
}

\author{
Aurélie Renvoise, Didier Raoult and Véronique Roux \\ Laboratoire de Bactériologie-Virologie, Hôpital de la Timone, CNRS UMR 6236, CNRS-IRD, IFR48, \\ 264 rue Saint-Pierre, 13385 Marseille Cedex 05, France
}

Correspondence

Véronique Roux

vroux91@hotmail.com

\begin{abstract}
Gram-positive, non-spore-forming rods (strain $4401292^{\top}$ ) were isolated from a human blood sample. Based on cellular morphology and the results of biochemical tests, this strain was tentatively identified as belonging to an undescribed species of the genus Actinomyces. Phylogenetic analysis based on 16S rRNA gene sequence comparison showed that the bacterium was related closely to Actinomyces gerencseriae (95.1\% 16S rRNA gene sequence similarity), Actinomyces israelii (95.2\%), Actinomyces oricola (95.2\%), Actinomyces ruminicola (93.3\%) and Actinomyces dentalis (91.4\%). The predominant fatty acids were C18: $1 \omega 9 \mathrm{c}$ and $\mathrm{C} 16: 0$. On the basis of phenotypic data and phylogenetic inference, the novel species Actinomyces massiliensis sp. nov. is proposed; the type strain is $4401292^{\top}{ }^{(=C S U R} \mathrm{P}_{18}{ }^{\top}$ $=$ CCUG 53522 $2^{\top}$.
\end{abstract}

The genus Actinomyces consists of a heterogeneous group of Gram-positive, anaerobic and aerotolerant, non-sporeforming, non-motile rods that have a high $\mathrm{G}+\mathrm{C}$ content. The natural habitats of Actinomyces are the mucous membranes of humans and animals, particularly the oral mucosa. They are aetiological agents of actinomycosis, which is a polymorphous disease that can be acute or chronic. Classical forms of the disease are cervicofacial, thoracic and abdominal. However, uterine, ocular, cerebrospinal and hepatic infections have also been described. Identification of representatives of the genus Actinomyces is often problematic in clinical laboratories (Sarkonen et al., 2001). Many studies based on phenotypic identification of members of the genus Actinomyces have been performed (e.g. Miller et al., 1995; Santala et al., 2004). Some of them proposed flowcharts for accurate differentiation (e.g. Sarkonen et al., 2001). However, molecular approaches are often more useful to identify and clarify the taxonomic positions of putative pathogens (Hall et al., 2001; Woo et al., 2003; Song, 2005). Many novel Actinomyces species have been described in recent years, most of which originated from human sources (Hall et al., 2003a, b, 2005; An et al., 2006). It remains important to clarify their roles in both ecology and infections (Clarridge \& Zhang, 2002).

In this report, we describe a novel species belonging to the genus Actinomyces that is related closely to Actinomyces gerencseriae and was isolated from a human blood sample.

The GenBank/EMBL/DDBJ accession number for the 16S rRNA gene sequence of Actinomyces massiliensis $4401292^{\top}$ is EF558367.

\section{Isolation and characterization of the strain}

A 38-year-old man was admitted to hospital in December 2003 for haemoptysis. He presented with cough, flu syndrome, fever $\left(38.5{ }^{\circ} \mathrm{C}\right)$, diarrhoea, asthenia and weight loss. Computed tomography examination showed pulmonary excavated lesions, which were treated by surgery. The patient was readmitted to hospital in April 2004, 1 month following pulmonary surgery, presenting with malaise, dyspnoea and basal thoracic pain. Blood cultures remained sterile, but a pleuropneumonia was diagnosed and the patient was treated empirically with $3 \mathrm{~g}$ cotrimoxazole day $^{-1}$ and $2 \mathrm{~g}$ ciprofloxacin day $^{-1}$ for 10 days. His condition improved quickly. Blood cultures were performed to follow the patient evolution and an anaerobic bacterium was isolated $\left(4401292^{\mathrm{T}}\right)$. Phenotypic identification was impossible to obtain, but genomic identification was obtained by $16 \mathrm{~S}$ rRNA gene sequence comparison. Strain $4401292^{\mathrm{T}}$ was identified as a representative of the genus Actinomyces.

Antimicrobial susceptibility was determined according to the criteria of the Clinical and Laboratory Standards Institute (CLSI), formerly the National Committee for Clinical Laboratory Standards (NCCLS). Strain $4401292^{\mathrm{T}}$ was susceptible to penicillin G, amoxicillin, cefotetan, vancomycin, imipenem, rifampicin, erythromycin, doxycycline, gentamicin and trimethoprim/sulfamethoxazole.

Surface colonies on sheep-blood agar (bioMérieux) were circular, white, shiny and pinpoint after $48 \mathrm{~h}$ anaerobic incubation. Growth and haemolytic activity were tested at $37{ }^{\circ} \mathrm{C}$ on $5 \%$ sheep-blood agar. Growth was tested in the presence of air, in $5 \% \mathrm{CO}_{2}$ and in anaerobic and microaerophilic atmospheres that were created by using 
GENbag anaer and GENbag microaer (bioMérieux), respectively. The ability of the strain to grow at different temperatures $\left(25,30,37,44\right.$ and $\left.50{ }^{\circ} \mathrm{C}\right)$ was investigated. Optimum growth was obtained at $37^{\circ} \mathrm{C}$, but occurred between 30 and $37^{\circ} \mathrm{C}$. The strain was anaerobic and also grew in microaerophilia and in $5 \% \mathrm{CO}_{2}$. The bacteria were non-haemolytic. The size and ultrastructure of cells were determined by transmission electron microscopy. Cells were grown on $5 \%$ sheep-blood agar for $24 \mathrm{~h}$. A bacterial suspension was pre-fixed in $5 \%(\mathrm{v} / \mathrm{v})$ glutaraldehyde in phosphate buffer (Gibco) for at least $1 \mathrm{~h}$ at room temperature, washed in the same buffer and stained with $1 \%(\mathrm{w} / \mathrm{v})$ phosphotungstic acid. Samples were examined on a Morgagni 268D (Philips) electron microscope at an operating voltage of $60 \mathrm{kV}$. The rods were $0.5-1.7 \mu \mathrm{m}$ long and $0.35-0.74 \mu \mathrm{m}$ wide.

Catalase activity, as determined by an ID Color Catalase test kit (bioMérieux), was negative. Oxidase activity, assayed by applying the cells to moistened discs impregnated with dimethyl-p-phenylenediamine (bioMérieux), was negative.

The commercially available API ZYM, API Rapid ID 32 A and API $50 \mathrm{CH}$ strips, combined with API $50 \mathrm{CHB} / \mathrm{E}$ medium (all from bioMérieux), were used to characterize the biochemical properties of the strain according to the manufacturer's instructions.

Phenotypic characteristics were compared with those of Actinomyces oricola CIP $107639^{\mathrm{T}}$, Actinomyces israelii CIP $103259^{\mathrm{T}}$, A. gerencseriae CIP $105418^{\mathrm{T}}$, Actinomyces naeslundii $\mathrm{CIP} 103128^{\mathrm{T}}$, Actinomyces viscosus CIP $103147^{\mathrm{T}}$ and Actinomyces catuli CIP $106507^{\mathrm{T}}$, which were the most closely related species when $16 \mathrm{~S}$ rRNA gene sequences were compared. Characteristic traits are presented in Table 1. Results of other tests for the type strain are given in the species description.

Preparation and determination of cellular fatty acids were carried out by following the procedures given for the Sherlock Microbial Identification system (MIDI). The major fatty acids were $\mathrm{C} 18: 1 \omega 9 c \quad(41.2 \%), \quad \mathrm{C} 16: 0$ $(34.0 \%), \mathrm{C} 18: 0(10.9 \%)$ and a mix of $\mathrm{C} 18: 0$ anteiso and $18: 2 \omega 6,9 c(10.9 \%)$. The predominance of $\mathrm{C} 16: 0$ and C18: $1 \omega 9 c$ was similar to the fatty acid profiles of other closely related members of the genus Actinomyces. However, the presence of a mix of $\mathrm{C} 18: 2 \omega 6,9 c$ and C18:0 $(10.9 \%)$ was characteristic of our isolate (Table 2).

\section{Genotypic characterization}

Bacterial DNA was extracted by using a MagNA Pure LC DNA isolation kit III (Roche) with a MagNA Pure LC instrument, as described by the manufacturer. PCR amplification of the 16S rRNA gene was performed by using the universal primer pair fD1 and rp2 (Weisburg et al., 1991). PCR products were purified by using MultiScreen PCR (Millipore) and sequencing reactions were carried out by using a DNA sequencing kit (BigDye Terminator Cycle Sequencing v1.1 Ready Reactions; PE Biosystems) according to the manufacturer's instructions. Sequencing products were purified and electrophoresis was performed with a 3130 Genetic Analyzer (Applied Biosystems). The obtained sequences were compared with sequences deposited in GenBank by using the BLAST program through the NCBI server. Gene sequences were aligned by using the multiple sequence alignment program CLUSTAL_X (1.8). Phylogenetic relationships with closely related species were determined by using MEGA version 4.0 (Tamura et al., 2007). Distance matrices were determined following the assumptions described by Kimura (1980) and were used to elaborate a dendrogram using the neighbour-joining method (Saitou \& Nei, 1987). The maximum-parsimony algorithm was also used to infer phylogenetic analysis. A bootstrap analysis (bootstrap values were obtained for a consensus tree based on 100 randomly generated trees) was performed to investigate the stability of the trees obtained. The clustering of the novel isolate was the same with the two methods. The phylogenetic analysis demonstrated that our isolate is a member of the genus Actinomyces. It clustered with $A$. gerencseriae and A. israelii (Fig. 1) and three other species: $A$. oricola, A. ruminicola and A. dentalis. Percentage similarities between $16 \mathrm{~S}$ rRNA gene sequences were determined by using NALIGN in the PC/GENE software package (IntelliGenetics). Similarities between strain $4401292^{\mathrm{T}}$ and A. gerencseriae DSM $6844^{\mathrm{T}}$, A. israelii CIP $103259^{\mathrm{T}}$, A. oricola CCUG $46090^{\mathrm{T}}$, A. ruminicola $\mathrm{B} 71^{\mathrm{T}}$ and A. dentalis $\mathrm{R} 18165^{\mathrm{T}}$ were 95.1, 95.2, 95.2, 93.3 and $91.4 \%$, respectively. All of these values are $<97 \%$, confirming that strain $4401292^{\mathrm{T}}$ belongs to a novel species (Stackebrandt et al., 2002) in the genus Actinomyces.

Based on the results described above, we propose the name Actinomyces massiliensis sp. nov. for the novel bacterium, with $4401292^{\mathrm{T}}$ as the type strain.

\section{Description of Actinomyces massiliensis sp. nov.}

Actinomyces massiliensis (mas.si.li.en'sis. L. masc. adj. massiliensis of Massilia, the old Greek and Roman name for Marseille, where the type strain was isolated).

Cells are anaerobic, Gram-positive, straight rods that are catalase- and oxidase-negative. Optimal growth occurs at $37{ }^{\circ} \mathrm{C}$. After $48 \mathrm{~h}$ growth on sheep-blood agar, surface colonies are pinpoint. The rods are $0.5-1.7 \mu \mathrm{m}$ in length and $0.35-0.74 \mu \mathrm{m}$ in diameter, as estimated by electronic microscopy. By using API ZYM, leucine arylamidase, valine arylamidase, $\beta$-galactosidase and $\alpha$-glucosidase activities are detected. Alkaline phosphatase, esterase (C4), esterase lipase (C8), lipase (C14), cystine arylamidase, trypsin, $\alpha$-chemotrypsin, acid phosphatase, naphthol-AS-BI-phosphohydrolase, $\alpha$-galactosidase, $\beta$-glucuronidase, $\beta$-glucosidase, $\quad N$-acetyl- $\beta$-glucosaminidase, $\alpha$-mannosidase and $\alpha$-fucosidase activities are not detected. By using API 50 $\mathrm{CH}$ strips after an incubation time of $24 \mathrm{~h}$, acid is produced from D-galactose, D-glucose, D-fructose, maltose, lactose, sucrose and trehalose. After an incubation time of $48 \mathrm{~h}$, acid is produced from D-xylose, melezitose, turanose 
Table 1. Diagnostic traits of species tested in this study

Taxa: 1, A. massiliensis $4401292^{\mathrm{T}} ; 2$, A. oricola CIP $107639^{\mathrm{T}} ; 3$, A. israelii CIP $103259^{\mathrm{T}} ; 4$, A. gerencseriae CIP $105418^{\mathrm{T}}$; 5, A. naeslundii CIP $103128^{\mathrm{T}}$; 6, A. viscosus CIP $103147^{\mathrm{T}}$; 7, A. catuli CIP $106507^{\mathrm{T}}$. w +, Weakly positive. Acid production results were read after $24 \mathrm{~h}$; some strains showed a different result at $48 \mathrm{~h}$ (in parentheses). API ZYM and API 32 ANA results were read after $4 \mathrm{~h}$. All taxa were positive for proline arylamidase and growth at $37^{\circ} \mathrm{C}$.

\begin{tabular}{|c|c|c|c|c|c|c|c|}
\hline Test & 1 & 2 & 3 & 4 & 5 & 6 & 7 \\
\hline \multicolumn{8}{|l|}{ Acid production from: } \\
\hline Glycerol & - & - & - & - & - & $-(+)$ & - \\
\hline L-Arabinose & - & - & - & - & - & - & + \\
\hline D-Ribose & $-(w+)$ & - & + & - & - & - & + \\
\hline D-Xylose & $-(+)$ & - & + & - & - & - & + \\
\hline D-Galactose & + & - & + & - & - & + & + \\
\hline D-Glucose & + & - & + & $-(+)$ & + & + & + \\
\hline D-Fructose & + & - & + & - & + & + & + \\
\hline D-Mannose & $-(w+)$ & - & + & - & $-(+)$ & + & + \\
\hline Inositol & - & - & $-(+)$ & - & $-(+)$ & + & - \\
\hline D-Mannitol & - & - & $-(+)$ & - & - & - & - \\
\hline Methyl- $\alpha$-D-glucopyranoside & - & - & - & - & - & - & $-(+)$ \\
\hline$N$-Acetylglucosamine & - & - & - & - & + & $-(+)$ & + \\
\hline Amygdalin & - & - & + & - & - & - & + \\
\hline Arbutin & - & - & + & - & $-(+)$ & + & + \\
\hline Aesculin & - & - & + & + & + & + & + \\
\hline Salicin & - & - & + & $\mathrm{w}+$ & + & + & + \\
\hline Cellobiose & - & - & + & - & - & - & + \\
\hline Lactose & + & - & + & + & - & + & + \\
\hline Melibiose & - & - & + & - & + & + & + \\
\hline Trehalose & + & - & + & - & + & + & + \\
\hline Melezitose & $-(+)$ & - & - & - & - & - & - \\
\hline Raffinose & - & - & + & $-(w+)$ & + & + & + \\
\hline Starch & - & - & - & - & - & - & + \\
\hline Gentiobiose & - & - & $-(+)$ & - & - & - & + \\
\hline Turanose & $-(+)$ & - & - & $-(w+)$ & - & - & + \\
\hline D-Lyxose & $-(+)$ & - & $-(+)$ & - & - & - & + \\
\hline L-Fucose & - & - & - & - & - & + & - \\
\hline Potassium 5-ketogluconate & - & - & - & $-(w+)$ & - & - & - \\
\hline \multicolumn{8}{|l|}{ API ZYM: } \\
\hline Esterase (C4) & - & - & $\mathrm{w}+$ & + & - & + & - \\
\hline Valine arylamidase & + & - & - & + & - & - & - \\
\hline$\alpha$-Galactosidase & - & - & - & - & + & - & - \\
\hline$\beta$-Galactosidase & + & - & + & + & + & + & + \\
\hline$\alpha$-Glucosidase & + & + & + & + & - & - & + \\
\hline$\beta$-Glucosidase & - & + & + & + & + & + & + \\
\hline \multicolumn{8}{|l|}{ API 32 ANA: } \\
\hline Arginine dihydrolase & - & - & + & + & - & - & + \\
\hline$\alpha$-Galactosidase & - & $\mathrm{w}+$ & + & + & + & + & + \\
\hline$\beta$-Glucosidase & - & + & + & + & + & + & + \\
\hline$\alpha$-Arabinosidase & - & - & + & + & - & - & + \\
\hline$\beta$-Glucuronidase & - & - & - & - & - & - & + \\
\hline$N$-acetyl- $\beta$-glucosaminidase & - & - & - & - & - & - & + \\
\hline Glycine arylamidase & - & - & - & - & + & - & - \\
\hline Histamine arylamidase & - & - & - & - & + & - & - \\
\hline Raffinose fermentation & - & + & + & + & + & + & + \\
\hline Indole production & - & - & - & - & - & - & + \\
\hline
\end{tabular}


Table 1. cont.

\begin{tabular}{|c|c|c|c|c|c|c|c|}
\hline Test & 1 & 2 & 3 & 4 & 5 & 6 & 7 \\
\hline \multicolumn{8}{|l|}{ Growth in/at: } \\
\hline Aerobic atmosphere & - & - & - & - & + & + & + \\
\hline $5 \% \mathrm{CO}_{2}$ & + & - & - & $\mathrm{w}+$ & + & + & + \\
\hline Microaerophilic atmosphere & + & $\mathrm{w}+$ & $\mathrm{w}+$ & $\mathrm{w}+$ & + & + & + \\
\hline Anaerobic atmosphere & + & + & + & + & + & + & + \\
\hline $25{ }^{\circ} \mathrm{C}$ & - & - & $\mathrm{w}+$ & - & + & + & $\mathrm{w}+$ \\
\hline $30{ }^{\circ} \mathrm{C}$ & $\mathrm{w}+$ & - & $\mathrm{w}+$ & + & + & + & + \\
\hline $44{ }^{\circ} \mathrm{C}$ & - & - & - & - & + & + & - \\
\hline
\end{tabular}

Table 2. Whole-cell fatty acid compositions (\%) of the novel Actinomyces isolate and related species

ND, Not detected. Data for A. massiliensis are from the current study; data for A. oricola are from Hall et al. (2003a); data for A. ruminicola and A. israelii are from An et al. (2006); data for A. nasicola are from Hall et al. (2003b).

\begin{tabular}{|c|c|c|c|c|}
\hline Species & C16:0 & Mix of $\mathrm{C} 18: 2 \omega 6,9 c$ and $\mathrm{C} 18: 0$ anteiso & $\mathrm{C} 18: 1 \omega 9 c$ & C18:0 \\
\hline A. massiliensis & 34.0 & 10.9 & 41.2 & 10.9 \\
\hline A. oricola & 44 & $\mathrm{ND}$ & 37 & 14 \\
\hline A. ruminicola & 34.64 & ND & 25.33 & 15.91 \\
\hline A. nasicola & 29 & ND & 26 & 11 \\
\hline A. israelii & 38.9 & ND & 33.4 & 2.5 \\
\hline
\end{tabular}

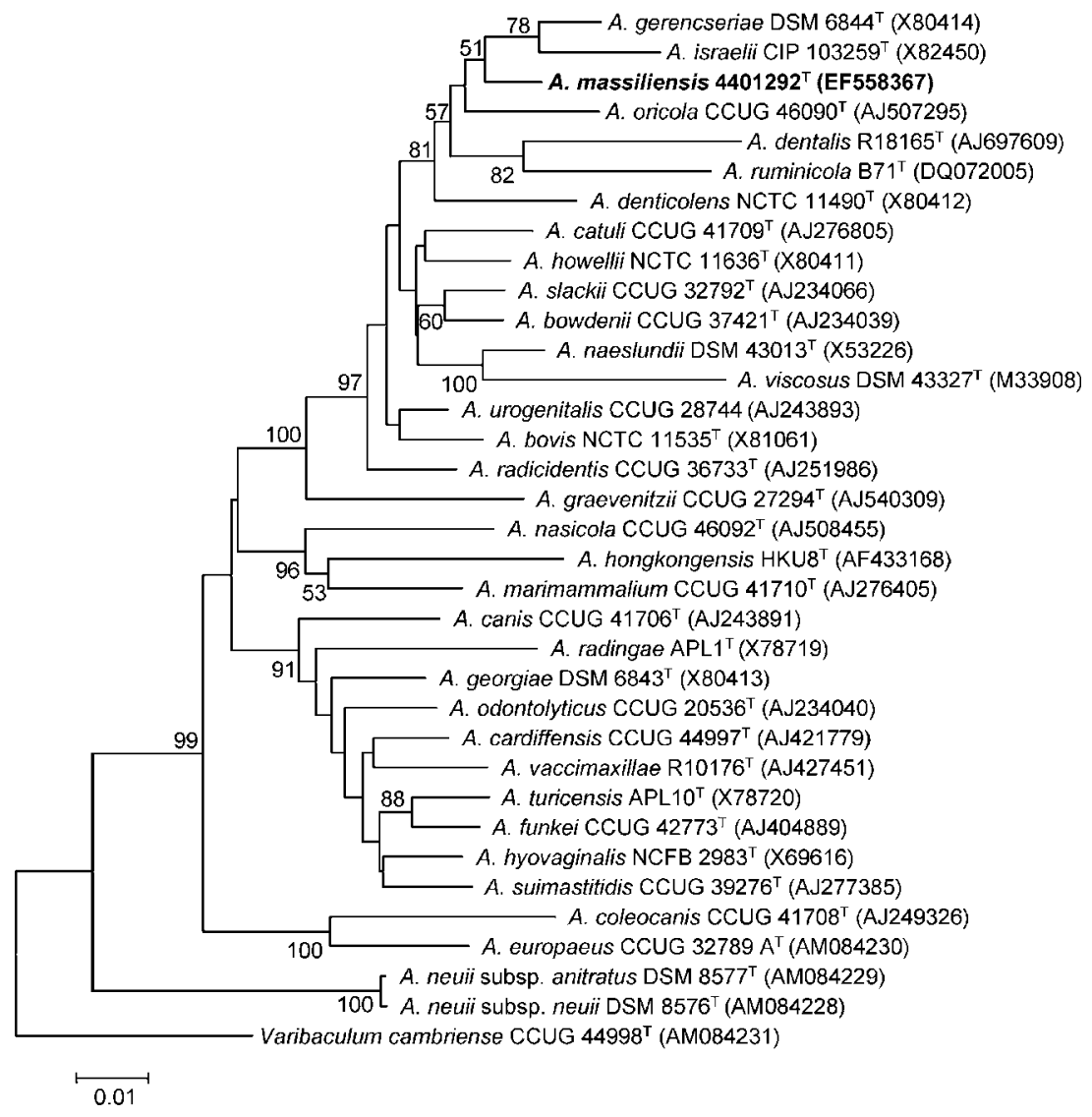

Fig. 1. Phylogenetic tree of representatives of the genus Actinomyces inferred from 16S rRNA gene sequence comparison (1358 nt fragment). Numbers at nodes are proportions of 100 resamplings that support the topology shown; values $>50 \%$ are indicated. Varibaculum cambriense was used as the outgroup. Bar, 0.01 nucleotide change per nucleotide position. 
and D-lyxose. After an incubation time of $48 \mathrm{~h}$, acid is produced weakly from D-ribose and D-mannose. Acid is not produced from glycerol, erythritol, D-arabinose, Larabinose, $\mathrm{L}$-xylose, D-adonitol, methyl $\beta$-D-xylopyranoside, L-sorbose, L-rhamnose, dulcitol, inositol, D-mannitol, Dsorbitol, methyl $\alpha$-D-mannopyranoside, methyl $\alpha$-D-glucopyranoside, $\mathrm{N}$-acetylglucosamine, amygdalin, arbutin, aesculin ferric citrate, salicin, cellobiose, melibiose, inulin, raffinose, starch, glycogen, xylitol, gentiobiose, D-tagatose, D-fucose, Lfucose, D-arabinol, L-arabinol, potassium gluconate, potassium 2-ketogluconate or potassium 5-ketogluconate. By using API Rapid ID $32 \mathrm{~A}$, the following tests were positive: $\beta$ galactosidase, $\alpha$-glucosidase, reduction of nitrates, proline arylamidase, phenylalanine arylamidase and leucine arylamidase. Mannose fermentation and tyrosine arylamidase were weakly positive. The remaining tests were negative: urease, arginine dihydrolase, $\alpha$-galactosidase, $\beta$-galactosidase 6 -phosphate, $\beta$-glucosidase, $\alpha$-arabinosidase, $\beta$-glucuronidase, $N$ acetyl- $\beta$-glucosaminidase, raffinose fermentation, glutamic acid decarboxylase, $\alpha$-fucosidase, indole production, alkaline phosphatase, arginine arylamidase, leucyl glycine arylamidase, pyroglutamic acid arylamidase, alanine arylamidase, glycine arylamidase, histamine arylamidase, glutamyl glutamic acid arylamidase and serine arylamidase. The fatty acid profile is

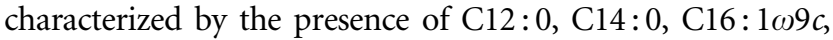
$\mathrm{C} 16: 1 \omega 7 c$, $\mathrm{C} 16: 0$, a mix of $\mathrm{C} 18: 2 \omega 6,9 c$ and $\mathrm{C} 18: 0$ anteiso, $\mathrm{C} 18: 1 \omega 9 c$ and $\mathrm{C} 18: 0$.

The type strain, which was isolated from a human blood sample, is $4401292^{\mathrm{T}}\left(=\right.$ CSUR P $18^{\mathrm{T}}=$ CCUG $\left.53522^{\mathrm{T}}\right)$.

\section{Acknowledgements}

We are grateful to Bernard Campagna and Nicolas Aldrovandi for their technical assistance in electronic microscopy and to Enevold Falsen (University of Göteborg, Sweden) for the cellular fatty acid composition profile.

\section{References}

An, D., Cai, S. \& Dong, X. (2006). Actinomyces ruminicola sp. nov., isolated from cattle rumen. Int J Syst Evol Microbiol 56, 2043-2048.

Clarridge, J. E., III \& Zhang, Q. (2002). Genotypic diversity of clinical Actinomyces species: phenotype, source, and disease correlation among genospecies. J Clin Microbiol 40, 3442-3448.
Hall, V., Talbot, P. R., Stubbs, S. L. \& Duerden, B. I. (2001). Identification of clinical isolates of Actinomyces species by amplified $16 \mathrm{~S}$ ribosomal DNA restriction analysis. J Clin Microbiol 39, 3555-3562.

Hall, V., Collins, M. D., Hutson, R. A., Inganas, E., Falsen, E. \& Duerden, B. I. (2003a). Actinomyces oricola sp. nov., from a human dental abscess. Int J Syst Evol Microbiol 53, 1515-1518.

Hall, V., Collins, M. D., Lawson, P. A., Falsen, E. \& Duerden, B. I. (2003b). Actinomyces nasicola sp. nov., isolated from a human nose. Int J Syst Evol Microbiol 53, 1445-1448.

Hall, V., Collins, M. D., Lawson, P. A., Falsen, E. \& Duerden, B. I. (2005). Actinomyces dentalis sp. nov., from a human dental abscess. Int J Syst Evol Microbiol 55, 427-431.

Kimura, M. (1980). A simple method for estimating evolutionary rates of base substitutions through comparative studies of nucleotide sequences. J Mol Evol 16, 111-120.

Miller, P. H., Wiggs, L. S. \& Miller, J. M. (1995). Evaluation of API AnIDENT and RapID ANA II systems for identification of Actinomyces species from clinical specimens. J Clin Microbiol 33, 329-330.

Saitou, N. \& Nei, M. (1987). The neighbour-joining method: a new method for reconstructing phylogenetic trees. Mol Biol Evol 4, 406-425.

Santala, A. M., Sarkonen, N., Hall, V., Carlson, P., Jousimies-Somer, H. \& Kononen, E. (2004). Evaluation of four commercial test systems for identification of Actinomyces and some closely related species. J Clin Microbiol 42, 418-420.

Sarkonen, N., Kononen, E., Summanen, P., Kononen, M. \& Jousimies-Somer, H. (2001). Phenotypic identification of Actinomyces and related species isolated from human sources. J Clin Microbiol 39, 3955-3961.

Song, Y. (2005). PCR-based diagnostics for anaerobic infections. Anaerobe 11, 79-91.

Stackebrandt, E., Frederiksen, W., Garrity, G. M., Grimont, P. A. D., Kämpfer, P., Maiden, M. C. J., Nesme, X., Rossello-Mora, R., Swings, J. \& other authors (2002). Report of the ad hoc committee for the re-evaluation of the species definition in bacteriology. Int $J$ Syst Evol Microbiol 52, 1043-1047.

Tamura, K., Dudley, J., Nei, M. \& Kumar, S. (2007). MEGA4: molecular evolutionary genetics analysis (MEGA) software version 4.0. Mol Biol Evol 24, 1596-1599.

Weisburg, W. G., Barns, S. M., Pelletier, D. A. \& Lane, D. J. (1991). 16 S ribosomal DNA amplification for phylogenetic study. J Bacteriol 173, 697-703.

Woo, P. C., Ng, K. H. L., Lau, S. K. P., Yip, K. T., Fung, A. M. Y., Leung, K. W., Tam, D. M. W., Que, T. L. \& Yuen, K. Y. (2003). Usefulness of the MicroSeq 500 16S ribosomal DNA-based bacterial identification system for identification of clinically significant bacterial isolates with ambiguous biochemical profiles. J Clin Microbiol 41, 1996-2001. 